\section{THE FRENCH MEDICAL SERVICE IN THE FIELD.}

By R. J. BlackhaM, C.B., C.M.G., C.I.E., D.S.O., M.D., COLONET, LATE A.M.S.

With assistance from G. LEMoINe, C.B., Médecin Inspecteur-Général ; and O. GaRRET, Médecin Major de 1re Classe.

ON the Italian front an interesting feature of the campaign was the opportunities afforded for the study of the French Army Medical Service. After returning to France, whilst serving with a corps forming portion of a French army, I had a unique opportunity of checking and expanding my notes prepared in Italy, and now submit them in the hope that they may not only be of interest, but possibly facilitate the work of British medical officers who have the privilege of working with French medical formations.

The Service de Santé.-I'he French Medical Service is called the "Service de Santé," and consists of officers and personnel.

The officers are: (1) Des Médecins (Medical Officers); (2) Des Pharmaciens (Pharmacists); (3) Des Officiers d'Administration (Medical Quartermasters).

The personnel consist of Infirmiers and Brancardiers, who are the rank and file of the medical serviee.

The grades of personnel are: (1) Sous-Aides Majors, Médecins Auxiliaires (Medical Students), and Dentistes Militaires; (2) SousOfficiers, Adjudants-Chef, Adjudants (Serg. Majors), Sergents, and Caporaux (as in the infantry).

Grades of French medical officers.-The grades in the French Medical Service are :-

Médecin Inspecteur-Général, ranking as Lieutenant-Genera1.

Inspecteur,

Principal de

Major de lre

Major de lre classe,

Mide-Major de classe,

Aide-Major de lre classe

Phärmacien In

Principal de lre classe,

Major de lre classe,

Major de lre classe,

Major de 2 me classe,

Aide-Major de 2 me classe, ", Major-General.

Colonel.

Lieutenant-Colonel.

Major.

Major.

Captain.

Lieutenant.

Sub-Lieutenan

Majox-Gen
Colonel:

Coloutenant-Colonel.

Major:

Captain.

Sub-Lieutenant

Officiers d'administration are graded as first-, secondand third-class, and rank as captain, lieutenant, and sub-lieutenant. A few reach the grade of officier d'administration principal, with the rank of major. The médecin auxiliaires have the rank of adjutant or warrant officers, but are treated as officers by their commissioned superiors. We have nothing at all resembling them in the British Medical Service, as the assistant surgeons employed with the British Army in India are Europeans or Eurasians who have been through a complete medical curriculum in a Government college and have been granted a diploma qualifying them to practise in British India.

"Les officiers du Corps de Santé en France sont une hiérarchie propre comprenant des grades correspondant aux grades d'officiers combattants, mais avec appellations spéciales; il n'y a pas égalité entre médecins et combattants, mais seulement assimilation. Un Médecin Major de 2 me classe n'est pas un capitaine. Un Médecin Major de lre classe n'est pas un commandant; il est un peu moins. L'officier combattant a toujours, a égalité de galons, la préséance sur l'officier des services (Santé, Intendance, Service Vétérinaire. \&e.)" (Garret.)

Uniform.-The field uniform of the French Medical Service is the same as that of other officers. They wear a gorget patch of cherry-coloured velvet with the snake of Asculapius (le caducée) enclosed in an oval laurel wreath. The pharmaciens wear green velvet gorget patches. The quartermasters (officiers d'administration) wear a ten-pointed golden star on a red velvet background. Military dentists wear the uniform of adjudants of sections d'infirmiers, with the caducée in silver aceompanied by the letter " $\mathrm{D}$ " on the collar. The letter is $1 \mathrm{~cm}$. in size and placed externally to the caducée. They do not wear any braid of rank on "képi" or on the sleeve. The badges of rank of both médecins and pharmaciens are of gold.

The rank and file.-The rank and file of the French Medical Service is divided into two well-defined classes, infirmiers or hospital orderlies, and brancardier's or stretcher-bearers. I have always had great difficulty in explaining to French offcers visiting my fleld ambulances that the rank and file of the R.A.M.C. with a field unit are fully qualified to act in either capacity.

The specially trained infirmiers (infirmiers de visite) always function as hospital orderlies and are dis tinguished by wearing on their collar a white caducée (snake and rod of Asculapius) on a red background. The other infirmiers (infirmiers d'exploitation) carry out manual labour in the hospitals and may function as stretcher-bearers. On the other hand, in the divisional bearer company or the corps bearer company of brancardiers, a certain number of stretcher-bearers are employed in the special work of the infirmiers de visite.

$$
\text { Zones of the Medical Service. }
$$

The French Medical Service in the field is divided into two zones: (a) Service de Santé de l'avant; and (b) Service de Santé de l'arrière.

\section{A. Service de Santé de l'Avant.}

The direction of the medical services with the field army differs in many ways from the British.

(a) The Médecin Inspecteur-Général corresponds to our DirectorGeneral.

(b) With each group of armies there is an Inspecteur du Service de Santé au Groupe d'Armées. He has no analogue in our Service. (c) With each army there is a Chef Supérieur du Service de Santé de l'Armée, corresponding to our Director of Medical Services.

(d) Each corps (corps d'armée) has a Directeur du Service de Santé du Corps d'Armée, who corresponds to our Deputy Director of Medical Services.

(e) Each French division has a Médecin Divisionaire, who corresponds to our Assistant Director of Medical Services.

The medical organisation of a French division differs in many ways from ours. There are the following formations: The Regimental Medical Service; the G.B.D., or Groupe des Brancardiers Divisionairesi.e., Divisional Bearer Company; the S.S.A., or Section Sanitaire Automobile (Divisional Motor Ambulance Convoy); and the Ambulances or Field Hospitals (usually two).

The Regimental Medical Service.

The first thing which the British student of the organisation of the continental military systems has to understand is that a "regiment" corresponds to what we call a "brigade" in the British Service. Prior to the introduction of the Territorial system in our army, what are now known as "battalions" were distin. guished by numbers and known as " regiments." Now, of course, the regiment embraces at least two regular battalions, sometimes one or two Special Reserve battalions, several Territorial battalions, and an unlimited number of Service battalions.

In our army four battalions, usually from four different "regiments," are grouped together for war purposes as a brigade.

Each infantry regiment in the French army has three battalions. Each battalion has four companies, of which one is a machine-gun company. In medical charge is a médecin chef du régiment, except in the Chausseur divisions. This officer may be a médecin major de 1re classe or a médecin principal de $2 m e$ classe, but is usually the former. He is on the staff of the colonel of the regiment, who corresponds to our brigadier. One of his principal functions is the charge of the poste de secours régimentaire and infirmerie. There is also a pharmacien du régiment who is under the orders of the médecin chef du service. Each infantry battalion should have a medical officer and a medical subordinate-i.e., a médecin aide-major de 1re or 2 me classe and a médecin auxiliaire (junior medical student). In the Chausseur divisions each company has either a médecin major de 2 me classe or a médecin auxiliaire. The battalion medical officers serve under the médecin chef du régiment, and not directly under the A.D.M.S. as in oux army, except of course, in the Chausseur divisions, where there is no médecin chef $d u$ régiment. Each regiment has a sergeant of stretcherbearers. Each battalion has 16 regular stretcherbearers and 16 additional when required, exactly as in our army.

There are, in addition, four hospital orderlies (infirmiers) with a corporal infirmier in charge, for each battalion. The battalion medical officers form postes de secours, which correspond exactly with our 
regimental aid-posts. As a rule, there are two of these battalion postes, one as near as possible to the front line, at which the médecin auxiliaire is stationed, and one farther back in charge of the médecin. In addition to the battalion postes there is a poste de secours régimentaire, where sick likely to recover in a few days are kept, to avoid their evacuation to the ambulances. This formation is practically a regimental rest station and has no analogue in our system.

Wounded are carried by the regimental bearers (Brancardiers du Régiment) from the front line to the regimental aid-posts, where they are taken over by the Groupe de Brancardiers Divisionaires which functions as the bearer divisions of our field ambulances, but, as will be seen below, is a distinct medical unit. Except during active operations the G.B.D. do not work up to the Postes de Secours and the regimental bearers carry the wounded back to the Relais de G.B.D., or bearer-posts.

Each battalion of infantry has a medical cart corresponding to our Maltese cart, which carries only the following material: (1) One medical pannier (2) one surgical pannier; (3) two panniers with dressing material; and (4) two panniers with a reserve of dressing material. It is two-wheeled and drawn by one horse. The cart also carries a surgical haversack for each company stretcher squad, an orderly's pouch for each hospital orderly, a medical companion for the battalion, printed forms, 2 lanterns, 1 Red Cross flag, 20 brassards, 20 one-litre water-bottles, a water-barrel, a pouch for treating cases of asphyxia or drowning, and 8 stretchers. A four-wheeled ambulance-wagon for the transport of sick and wounded is detached from the Groupe des Brancardiers Divisionaires and placed at the disposal of each regiment of infantry on the march.

The G.B.D., or Groupe des Brancardiers Divisionaires.

This unit is the divisional bearer company, and is under the orders of the médecin divisionaire. A "groupe" consists of the following personnel: One médecin chef, who is a médecin major; two médecins aide-majors; one pharmacien ; one officier d'administration; one médecin auxiliaire; three pharmaciens auxiliaires and 108 bearers. It has the following transport: One four-wheeled vehicle; eight two-wheeled vehicles ; 30 wheeled stretcher carriers.

The system of working this unit is as follows:-

(1) Poste de Secours.-Detachments of the G.B.D. are, during battle, attached to the battalion aid-posts (Postes de Secours).

(2) Relais de G.B.D.-Within reasonable distance of the aid-posts is the relay post of

(3) Poste de Recueil. - This corresponds roughly to our advanced dressing station, and is the point at which motor ambulance cars, horsed ambulance wagons, and wheeled stretchers are kept.

(4) Poste Central G.B.D.-This is the headquarters of the G.B.D., and is also the headquarters of the Section Sanitaire Automobile. Magasin de Material Anti-gas: (2) Laboratoire de Toxicologie; (3) Cabinet Dentaire; (4) Dépôt de Désinfectants.

Section Sanitaire Automobile "Ambulances."

This is the French analogue of our motor ambulance convoy. It consists of 20 motor ambulance cars and one touring car. Normally, each division has one section attached to it. In divisions these cars are usually attached to, and work with, the G.B.D. (see disposition above), but there are also some cars attached to the "distributing" ambulance-i.e., l'Ambulance de Triage. These cars evacuate cases as far back as the Hôpitaux d'évacuation. The section is commanded by a lieutenant of the French Automobile Service, and has no medical personnel. The S.S.A. are replaced in some cases by American formations, which are groups of 40 Ford cars, replacing the 20 Fiat ambulance cars of the ordinary French units. In case of an offensive the corps adds more S.S.A. for the whole corps front. In a French army consisting of two corps of two divisions, two divisions are in the line and two in reserve. This gives 50 ambulance cars to evacuate each divisional front.

In addition each army has one to four S.S.A. in reserve for disposal where necessary. One S.S.A. is allotted to each hospital of evacuation for the transfer of special cases, or for evacuating to other hospitals.
In the French army the term "ambulance" is employed in the sense of field hospital. The personnel of an ambulance is as follows:-

8 officers $\{5$ médecins (of which one is the médecin chef). 1 pharmacien.

officiers d'administration.

and 32 other ranks (infirmiers).

The strength of the rank and file roughly corresponds to one and a half "tent subdivisions" of a British field ambulance. The number of ambulances attached to a division varies according to its needs. There are usually two. They are moved about by the Directeur du Service de Santé du Corps d'Armée, but when with the division they are under the orders of the médecin divisionaire.

When not taken over and pooled under corps arrangements divisional ambulances are employed as follows (1) One is the ambulance de triage, which distributes cases and also keeps cases not fit to travel, and lightly wounded who will quickly recover. It corresponds roughly to our divisional dressing station. (2) Another ambulance is used as a small hospital, corresponds to our divisional rest-station, and takes sick, lightly wounded, venereal and slight skin cases.' There is accommodation for 150 patients, and the periods of their stay in the ambulance is usually limited to three weeks.

The Ambulance de Triage has attached to it a Groupe Complémentaire de Chirurgie (G.C.C.) which has no analogue in our service. Each of these groupes. has as transport one lorry with a trailer which carries com plete equipment for forming an advanced operating centre and radiological department. The materia carried is sufficient for an operating-room, and anæs thetic room, and an X ray room. These rooms are lighted by electricity, and there is a complete plant for providing sterilised water and for heating the operating-theatre. On arrival at the unit to which it is attached the G.C.C. is worked by the surgical staff of the ambulance.

It will be seen that the médecin divisionaire $h a s$ under his administration the Group des Brancardiers Divisionaires and the Section Sanitairè Automobile. The two ambulances and the G.C.C. may, and often are, pooled by the D.D.M.S. to form corps formations. Obviously his position is very different from that of a British A.D.M.S. The battalion medical officers and médecin chef du régiment are under the colonel of the regiment, and the médecin divisionaire exercises only technical supervision over the regimental medical establishments.

\section{Evacuation of Wounded : "Infirmeries:"}

It is an axiom of the French Military Service that all wounded should be operated upon as soon as possible after their wounds, and to obtain the best results this should be within the first 12 hours. The system of evacuation aims at bringing the wounded man to the operating-table in the minimum of time. Picked up by the stretcher-bearers of the regiment, the man is carried :-

i. To the Poste de Secours, where he is attended to by the médecin or the médecin auxiliaire.

ii. From this point, at first by divisional stretcher-bearers and then by horsed or motor ambulance, he is taken to the Ambulance de Triage, where the dressing is inspected and his destination decided upon.

iii. If the wound is serious (head, abdominal, or thorax) an further transport is dangerous he is admitted into the Poste Chirurgical Avance (G.C.C.), which is near the Ambulance de Triage.

iv. If he can stand two or three hours' journey he is taken to the H.O.E. (hôpitaux d'évacuation, corresponding to our casuaity clearing stations).

M. Garret puts the evacuation system very concisely, as follows :-

Poste de Secours.-Triage avec P.C.A.; puis H.O.E. voila les trois organes essentiels du Service de Santé du champ de bataille, tel qu'il est actuellement compris. Le reste : Relais de G.B.D., poste de recueil, ambulances divisionaires, infirmeries, ne sont

In addition to the ambulance pour petites malades each French division usually organises infirmeries which have no official analogue in our Service. They provide for the treatment of very slight cases of illness quite close to the front line. The-patients are not shown as admissions to any medical formation. The 
establishment is the médecin chef of the regiment in reserve, assisted by a medical officer and the medical orderlies from battalions in reserve.

$$
\text { Burial of the Dead. }
$$

A stritking difference between the French and British armies is the arrangement for burial of the dead. In the British army this is arranged for by the adjutantgeneral's branch, but in the French army the burial of the dead is in the hands of the medical service. The G.B.D. of a division is responsible for the carriage of dead from Relais de G.B.D. to the cemeteries in rear. Special vehicles for the dead are provided. The

\section{EVACUATION OF WOUNDED \& SICK} from

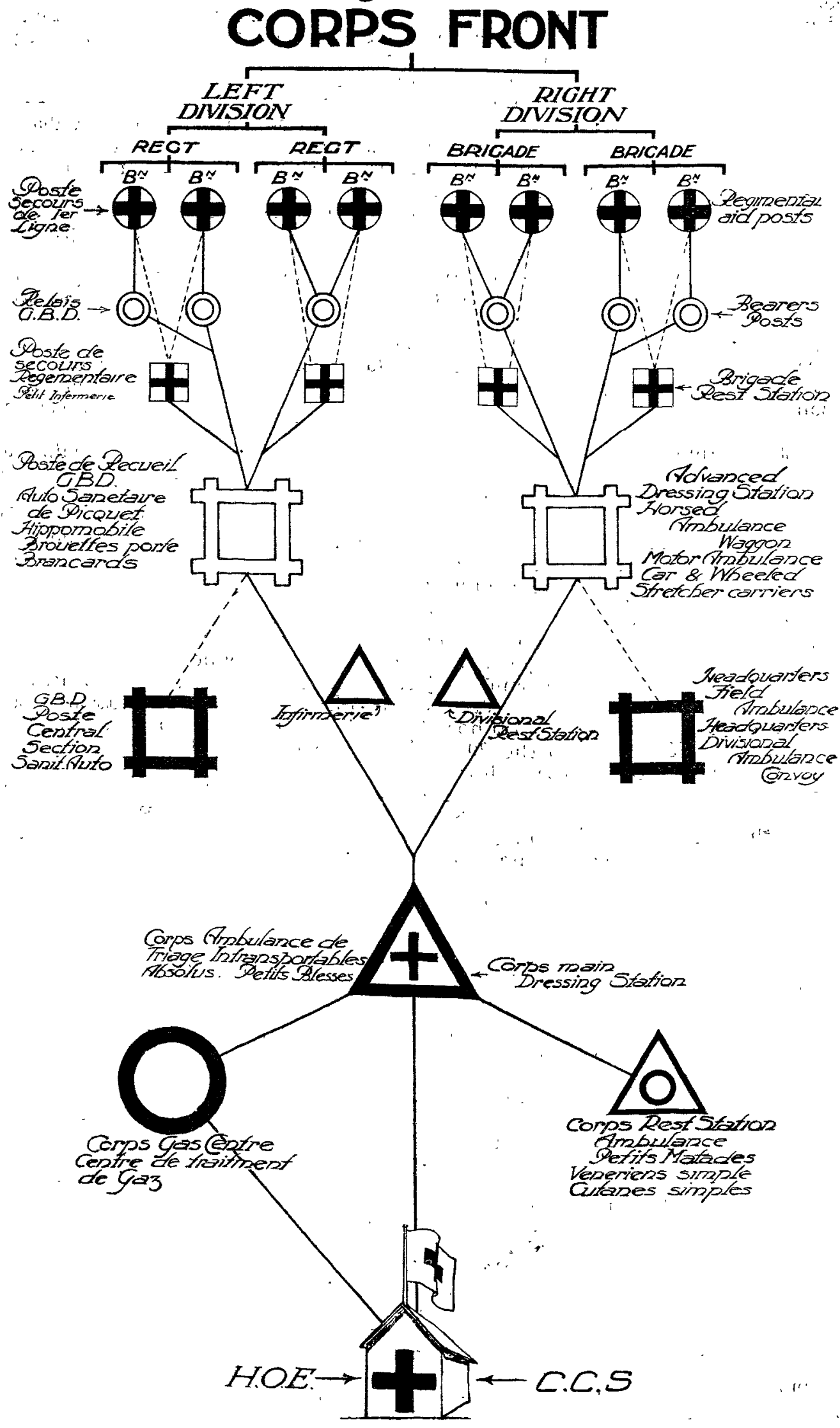

cemeteries of the forward area are under the charge of the G.B.D. The French display an immense amount of effort to do honour to their soldiers, " morts au champ d'honneur." Where practicable coffins are always provided. Their manufacture is in the hands of the Intendance, which corresponds to our Army Service Coxps.

Pharmacy and Dentistry in the French Medical Service.

One of the most remarkable differences between the French Medical Service and our own is the, very high position afforded to pharmacy. Whereas in our Service the dispensing of medicines is performed by corporals and sergeants, and the care of medical stores entrusted to our quartermasters, in the French army these duties are in the hands of a special body of officers, who hold the same rank as the medical officers. Important additional functions are also carried out by the pharmacien of the G.B.D. of each French division:-

(1) He acts as analytical chemist to the division and analyses and reports on all water supplies in the divisional area.

(2) In addition, he is not only the divisional gas officer, but has charge of all reserve supplies of masques and other defences against gas.

(3) $\mathrm{He}$ has charge of the divisional supply of disinfectants, which in our army is in the hands of the A.S.C.

In marked contrast to the high position held by pharmacy is the position accorded to dentistry by the French. The dentist is not an officer, but a sous-officier like the médecin auxiliaire. Each Groupe de Brancardiers Divisionaires has a dentist, and there is also a dentist for each regiment-i.e., three dentists per division. The general distribution of dentists is as follows:-

(A) Armies.-In front area formations: One dentist per Groupe des Brancardiers Divisionaires (divisional stretcher-bearers); one dentist per infantry regiment; one dentist per Groupe des Brancardiers du Corps (corps stretcher-bearers); one dentist per travelling dental centre.

(B) Lines of communication.-One dentist in each Centre Hospitaliere (group of hospitals); one dentist in each Dépôt d'Eiclopés (éclopés are very lightly wounded or sick).

(C) Base.-There is a dentist: (a) In each district where a dépôt of corps troops exists. He is attached to the military hospital, or failing this, to the most important medical formation in the area. (b) In each camp of instruction.

Military dentists are under the orders of the médecin chef of the formation to which they are attached.

The Medical Organisation of Corps, Armies, and Lines of Communication.

The medical organisation of a French corps is under the control of a Directeur du Service de Santé, who is a médecin principal de 1re classe. He corresponds to a British D.D.M.S. He has a staff officer, called adjoint, corresponding to a D.A.D.M.S. He has the following under his direct control. 
(1) Groupe des Brancardiers de Corps d'Armée. These G.B.C.. Groupe des Brancardiers de Corps d'Armée, are organised on exactly similar lines to the G.B.D., and employed as required by the corps d'armée. They constitute a corps reserve of stretcher-bearers.

(2) One S.S.A. de Corps d'Armée, and during active operations 20 lorries for lightly wounded.

(3) A varying number of ambulances allotted to him by the army.

Frequently the Directeur pools the whole of the divisional ambulances and arranges for the evacuation of all wounded to what corresponds to our corps main dressing station, a corps rest station, and a corps gas treatment centre. Each Directeur has on his staff a consulting surgeon.

The medical service of a French army is under a Chef Supérieur du Service de Santé de l'Armée, who is a médecin inspecteur with the relative rank of majorgeneral. He has on his staff one or two adjoints (D.A.D.M.S.), who are médecin majors of the 1re or 2me classe, a consulting surgeon, and a consulting physician. In addition he has four or five officers of administration. Of these:-

(1) One officer deals with the personnel.

(2) The second deals with the verification of all accounts. He is a sort of local auditor.

(3) The third deals with the inspection and administration of formations, and their upkeep and material.

(4) The fourth forms the link with the etat civil for deaths, burials, \&e.

The chef supérieur controls a variable number of the following medical formations:-

(1) Ambulances, which are usually grouped in H.O.E. (hôpitaux d'évacuation).

(2) Reserve sections sanitaire automobile (M. A.C's).

(3) Equipes, or surgical teams.

(4) Automobiles chirurgicales (organised groups of surgical teams)

H.O.E. (hospitals of evacuation).

6) Special gas treatment hospitals

(7) Special centres for: (a) eye; (b) ear, nose and throat; (c) enereal; $(d)$ skin ; $(e)$ mouth and face surgery ; $(f)$ fractures.

Behind the zone of the armies are the étapes, which correspond roughly to our lines of communication. They are under a Directeur du Service de Santé D. E. The étapes include various hospitals established for surgical and medical work or for the various specialities of medicine or surgery. They also include the secondary hospitals of evacuation.

The medical service of a group of French armies is under a Médecin Inspecteur-Général, who has the following staff: One or two médecin majors 1re or 2 me classe as adjoints; one officier d'administration. His functions are to carry out inspections on behalf of the Général en Chef and coördinate the work of the group of armies and the étapes.

$$
\text { B. Service de Santé d'Arrière. }
$$

Hôpitaux d'évacuation. -The first important formation of the service de santé vers l'arrière is the H.O.E.by the way, the French are as fond of alphabetical titles for medical formations as we are-which forms a link between the two zones, d'avant et d'arrière.

The hospitals of evacuation have three important functions: (a) triage or sorting of seriously wounded from slight cases; (b) evacuation of lightly wounded; (c) hospitalisation or treatment of seriously wounded.

The H.O.E. is administered by a senior regular officer of the service de santé, usually a médecin principal de 1re classe. He has usually under his command a total of 34 officers, 10 nurses, and 250 rank and file, but the establishment is not fixed. Hôpitaux d'évacuation are composite formations built up from a varying number of ambulances and surgical teams. In some cases the teams are in groups of six, called surgical units. The surgical unit has a trained personnel of 80 orderlies and nurses, and can deal with 500 beds. M. Lemoine describes this unit as the "cheville ouvrière" of surgery at the front.

French hospitals of evacuation have grown in size during trench warfare, like our own casualty clearing stations, until they have reached 2000 to 3000 beds. They are arranged in sections and embrace a varying number of what is known as auto-chirs under médecin chefs, who are well-known surgeons from Paris or one of the great medical schools.

The auto-chir, or automobile-chirurgical, has no direct analogue in our Service. It is an organised group of surgical teams. Each auto-chir has four équipes, which are similar to our surgical teams. They consist of one chirurgien, one aide-chirurgien, and two infirmiers, of which one acts as an anæesthetist. There are usually with each equipe two inflrmiers, supplied by one of the three societies forming the Croix Rouge Francaiseviz., La Société de Secours aux Blesses Militaires des Armées de Terre et Mer, L'Union des Femmes de France, and L'Association des Dames Francaises. The eight infirmiers of the auto-chir serve under an infirmiere major.

Hôpitaux d'évacuation have been recently divided into primaire and secondaire. There are two or three hôpitaux d'évacuation primaire for each army, but not at railheads. They function as clearing hospitals and operate only on cases not fit to leave, and they direct cases on the hôpitaux d'évacuation secondaire, which are situated 50 to $200 \mathrm{~km}$. behind the lines. They receive all the wounded fit to travel before operation. The primary hospitals of evacuation function for one army only, whereas the secondary hospitals function for a group of armies. These arrangements roughly correspond to the two echelons in which our own casualty clearing stations are now arranged.

Hospital trains and railway rest-stations. - The French trains sanitaires are similar to our ambulance trains, but there are three classes: (1) Trains sanitaires permanent. These are similar to our trains, and carry 100 lying and 200 sitting cases. (2) Trains sanitaires improvises. These are similar to our T.A.T., and hold 100 lying cases. (3) Ordinary third-class passenger trains. Taking éclopés, or very slight cases.

Within an hour's journey of the evacuating hospital is a Gare Régulatrice. Here a medical officer, called the régulatrice sanitaire, is stationed, whose duty is to check all dressings and to hold up any patients in the hospital at the Gare Régulatrice not considered fit to travel the long journey to the interior. No more than 10 to 12 trains per day are allowed to pass through any one Gare Régulatrice. We have no similar organisa. tion. Steam barges, carrying 80 to 100 patients lying or 124 mixed, are used to supplement the trains where possible, as in our own system.

Another special feature of the transport of wounded on the French railways is the Infirmeries de Gare, which are railway rest-stations of from 5 to 15 beds, and are formed by the French Red Cross.

\section{The Medical Organisation of the Interior.}

The Home Territory or "Interior" is organised in Régions d'Hôpitalisation, in which hospitals for the continuous treatment of wounds and sickness are established on similar lines to our stationary and general hospitals. There are 20 regions, corresponding to the 20 territorial corps of the French army. Each region has a Directeur du Service de Santé de la Région. who has an adjoint, or D.A.D.M.S., and corresponds to the A.D.M.S. of a district in Great Britain. In France, as in Great Britain, the military hospitals are largely augmented by auxiliary hospitals formed by the three French Red Cross Societies or by private bodies or individuals working under their auspices.

It will be seen that the following striking differences exist between the British and French gervices :-

1. The French medical officers have not got ordinary military titles as in our Service.

2. The French regiment has a regimental surgeon, who has no analogue in our Service, and the divisional organisation is largely based on a regimental system.

3. Pharmacists hold a rank and position in the French arm y unknown in ours, whereas dentistsare sous-officiers.

4. The French division, instead of having three field ambulances has $(a)$ a bearer company, (b) a motor ambulance convoy, $(c)$ two ambulances which are field hospitals purs et simples, and $(d)$ an advanced operating centre.

5. There is a grade of warrant officer for medical students performing medical duties for which we have no analogue, and there is a distinction drawn between the specially trained hospital or nursing orderly (infirmier) and the stretcher-bearer (brancardier). although the ordinary inflrmier may be called upon to act as a stretcher-bearer.

6. The French Corps has medical formations perma. nently allotted to it, and each corps has a consulting surgeon. 
7. The Medical Service of what corresponds to our L. of C. is under the Inspecteur du Service de Santé of a Group of Armies.

Attached is a diagrammatic plan showing the system of evacuation from a French corps front.

The following is a list of the chief French medical formations and the corresponding British equivalents :French.

(1) Postes de Secours. (2) Relais de G.B.D.

Poste de Recueil (G.B.D.)

(5) Poste Central (G.B.D.).

(5) Poste

(7) S.S.A.

(8) Ambulance de Triage.

(9) Ambulances pour Petits Malades.

(10) H.O.E. (Hôpitaux d' Gracuation). British. Regimental Aid-Post. arer-Posts.

Brigade Rest-Station.

Advanced Dressing Station.

Headquarters, Field Ambulance. M.A.C.

Corps Dressing Station.

Corps Gas Centre.

Corps Resti-Stations.

(a) Primaire. Casualty Clearing Station.

(b) Secondaire. Stationary Hospital.

Regimental or Divisional RestStation.

(11) Infirmerie

12) Dẻpôt d'Éclopés.

(13) Régulatrice Sanitaire. Army Rest-Station. Ambal Officer supervising
Ambulance Trains.

I have to thank M. le Médecin Inspecteur-Général Lemoine, C.B., lately of a Group of Armies, and now en retraite in Paris, M. le Médecin Inspecteur Lasnet, of the French Army of the Rhine, and M. le Médecin Major Garret for their valuable help and assistance in preparing these notes.

\section{STATE CARE OF MENTAL DISORDER.}

ANNUAL REPORT OF THE BOARD OF CONTROL (LUNACY AND MENTAL DEFICIENCY) FOR 1919.

THE sixth annual report of the Board of Control, covering the year 1919, has been issued, and can be purchased from H.M. Stationery Office for the modest sum of 1s., an appendix which-contains statistical tables and other details costing $9 s$. The report, as usual, is of great interest to medical practitioners, and deserves a much wider circulation than it. generally obtains. There is this year welcome evidence of more liberal spirit and, notably in one direction, of greater interest taken in the medical staff of the mental hospitals. The Board, moreover, has made six grants, amounting in all to $£ 1500$, for scientific research, showing that a beginning has been made by the State in seriously investigating the problems of insanity and mental deficiency. There can be no better use for public money than in the support of study of this kind. Not only does it mean a reduction of human suffering, but in the long run will prove a sound investment through the reduction in the cost to the community of the maintenance of the defective and mentally infirm.

Constitution of the Board.

The Board consists of 12 persons, two of whom are women, and the chairman is Sir W. P. Byrne. There are also two inspectors, whose duties are chiefly concerned with the supervision of mental defectives. The number of insane was (Jan. 1st, 1920) 116,764, an increase of 61 on the previous year. There were also 10,129 mental defectives, an increase of 1443 over the previous year. It may be calculated by a simple division sum that each member of the Board has on an average about 10,000 mentally infirm persons to "control." It is evident that a great deal is asked of the Commissioners, and the question arises whether some new arrangement is not overdue.

The actual exertion of personal control by members of the Board as regards the county and borough mental hospitals is limited to a single visit each year, when a hospital of about 800 or possibly 1000 patients is inspected in six hours by two Commissioners. A written report is made, and it is perhaps not surprising that local authorities do not always give as much weight to the Commissioners' findings as their special experience and authority should demand. Indeed, it may be feared that the Board of Control does not exercise the influence it used to do in asylum adminis- tration. The Board indeed admits as much, when it notes that it was not informed or consulted when far. reaching negotiations were arranged dealing with the hours and salaries of asylums officers.

The Need for a Central Authority.

Yet there is abundant evidence that a strong central authority is necessary. On the one hand, there is no reason to believe that human nature has so altered as to render supervision and inspection less needful in 1920 than it was in 1845 when the Commission in Lunacy was instituted. Truly horrible abuses prevailed until Lord Shaftesbury and the new Commissioners swept them away. The present report contains evidence that thoughtlessness, and even worse, still obtains, as we find that in two instances the Commissioners prosecuted nurses for assaulting patients, leading to conviction, and it may be assumed they would not have done this had not the local authority neglected its duty in the matter. But in the interest of the patients' health and recovery it is of the utmost importance that they should not be left entirely to the care of local authorities. No doubt some are up-todate and encourage their medical officers to do everything possible to promote the well-being of the patients ; but, unfortunately, others are indifferent, if not reactionary, and all are fearful of expense. So the medical officer fights single-handed for his patients' welfare, and only too frequently he loses heart and becomes discouraged. The temptation to become an economical administrator and to neglect medical science only too easily overwhelms him, the more so as his success is measured by his Committee rather by the relative lowness of the cost of maintenance than by his scientific attainments or his medical skill.

\section{Legal and Official Difficulties.}

It is often forgotten by those who criticise the Board of Control that it has to administer an Act of Parliament for which none of its present members were responsible, and which urgently demands amendment. Judges and Commissioners must not be blamed if the law is out of date, nor must they be asked to ignore the written statute. Many of the routine duties of the Board involve a burden that the public hardly realise. We believe it is still the practice for a member of the Board personally to read every medical certificate sent in, including every report made by medical officers relating to patients. Excluding mental deficiency 22,891 new patients were admitted during 1919 and 119,478 were in residence at the beginning of the year. When one thinks of the new certificates required, the constant stream of special reports for those under care, the weekly, monthly, yearly reports required by law, the death certificates, and that one or other of the Commissioners is expected to satisfy himself that these are all in order, it is evident the Board has no easy post.

The Board's history is interesting. From 1846 until six years ago the Commissioners in Lunacy were an independent body, appointed by the Lord Chancellor and reporting to him. The Chancellor represented the King, to whom all lunatics looked for protection. When the Board of Control was established it reported to the Home Secretary. The introduction of the word control emphasised its legal controlling power. The Prison Commissioners also report to the Home Office. Now, happily, the transfer to the Ministry of Health is completed and we may hope that less attention will be given to control and more to treatment and prevention. The problem is one of extreme difficulty, for safeguards are necessary directly an individual becomes mentally aflicted. We hope it may be possible to divorce these necessary safeguards more completely from the medical duties of the central authority. We have a vision of a new Board concerned with cure more than control, with research more than restraint, and with prevention rather than prosecution ; a Board whose duties include the provision of early treatment of mental disorders, as well as the custodial care of confirmed cases; a Board which stimulates intensive study of the causes of mental inflrmity; and further than this a Board whose members are 